\title{
Reef Fish Dispersal in the Hawaiian Archipelago: Comparative Phylogeography of Three Endemic Damselfishes
}

\author{
Kimberly A. Tenggardjaja, ${ }^{1}$ Brian W. Bowen, ${ }^{2}$ and Giacomo Bernardi ${ }^{1}$ \\ ${ }^{1}$ Department of Ecology and Evolutionary Biology, University of California Santa Cruz, 100 Shaffer Road, \\ Santa Cruz, CA 95060, USA \\ ${ }^{2}$ Hawaii Institute of Marine Biology, University of Hawaii, P.O. Box 1346, Kaneohe, HI 96744, USA \\ Correspondence should be addressed to Kimberly A. Tenggardjaja; kimberly.tenggardjaja@gmail.com
}

Received 2 November 2015; Accepted 8 March 2016

Academic Editor: Yehuda Benayahu

Copyright (C) 2016 Kimberly A. Tenggardjaja et al. This is an open access article distributed under the Creative Commons Attribution License, which permits unrestricted use, distribution, and reproduction in any medium, provided the original work is properly cited.

\begin{abstract}
Endemic marine species at remote oceanic islands provide opportunities to investigate the proposed correlation between range size and dispersal ability. Because these species have restricted geographic ranges, it is assumed that they have limited dispersal ability, which consequently would be reflected in high population genetic structure. To assess this relationship at a small scale and to determine if it may be related to specific reef fish families, here we employ a phylogeographic survey of three endemic Hawaiian damselfishes: Abudefduf abdominalis, Chromis ovalis, and Chromis verater. Data from mitochondrial markers cytochrome $b$ and control region revealed low but significant genetic structure in all three species. Combining these results with data from a previous study on Dascyllus albisella and Stegastes marginatus, all five endemic damselfish species surveyed to date show evidence of genetic structure, in contrast with other widespread reef fish species that lack structure within the Hawaiian Archipelago. Though individual patterns of connectivity varied, these five species showed a trend of limited connectivity between the atolls and low-lying Northwestern Hawaiian Islands versus the montane Main Hawaiian Islands, indicating that, at least for damselfishes, the protected reefs of the uninhabited northwest will not replenish depleted reefs in the populated Main Hawaiian Islands.
\end{abstract}

\section{Introduction}

Due to an apparent lack of barriers in the ocean and the potential for larvae to disperse long distances via ocean currents, the previously long-held paradigm has been that there is abundant connectivity and consequently little genetic differentiation between populations of marine organisms [1-3]. However, studies demonstrating self-recruitment and local larval retention indicate that not all marine organisms are exhibiting broad-scale larval dispersal [4-7]. In these circumstances, research has shifted toward understanding the factors mediating connectivity in marine systems and whether there are general patterns related to phylogenetic groups, pelagic larval duration, ecology, or behavior [8-11]. Nevertheless, generalizations have proven elusive.

Isolated oceanic islands provide an excellent opportunity for investigating dispersal in marine organisms. Rates of endemism are markedly high, and since endemic species are usually the products of long periods of isolated local recruitment and reproduction, they serve as model study organisms for understanding dispersal [5]. The general assumption has been that the constrained geographic range sizes of endemic species reflect limited dispersal abilities $[9,12,13]$, yet retention-favorable traits are not common characteristics of ocean island endemics $[5,14]$. For instance, pelagic larval duration (PLD) is a life history trait that provides an intuitive gauge of dispersal, by the logic that more time spent in the plankton results in greater dispersal and connectivity [15-17]. However, endemic reef fishes do not show a trend toward shorter PLDs relative to widespread congeners, and some studies have shown the opposite $[9,14,18]$.

While no diagnostic life history traits related to endemism have been identified, there is support for a positive correlation between dispersal ability and range size $[19,20]$. Eble et al. [21] sought to evaluate this relationship through a phylogeographic comparison in the Hawaiian Archipelago 
of three surgeonfishes (family Acanthuridae) with different geographic ranges. The Hawaiian endemic was predicted to exhibit less genetic connectivity (more genetic structure) than widespread members of the family. Results supported this hypothesis, with the endemic species demonstrating more, albeit weak, genetic structure than the two species with broader geographic distributions. In the Galapagos Islands, Bernardi et al. [22] surveyed reef fish species with varying range sizes, and again the endemic species demonstrated less genetic connectivity than species with broader distributions. Likewise, in a meta-analysis of tropical reef fishes, the relationship between range size and dispersal potential, as inferred from PLD, was found to vary between oceans, with a significant correlation demonstrated in the Indo-Pacific [20]. This relationship strengthened at higher taxonomic levels and was significant in the damselfishes (Pomacentridae), wrasses (Labridae), and butterflyfishes (Chaetodontidae), indicating that phylogenetic affiliation is a component of this relationship.

Here we assess genetic connectivity across the Hawaiian Archipelago, which is one of the most isolated archipelagoes in the world and has $25 \%$ endemism for shore fishes [23, 24]. The archipelago comprises eight Main Hawaiian Islands (MHI), which are "high islands" of volcanic basaltic composition, and ten Northwestern Hawaiian Islands (NWHI), which are mostly "low islands" with coral reefs and sand banks overgrowing subsided basaltic foundations [25]. In this study, we focused on three endemic Hawaiian damselfishes: Abudefduf abdominalis, Chromis ovalis, and Chromis verater. These three species have ranges that span the entire Hawaiian Archipelago, and C. verater is also found at Johnston Atoll, about $860 \mathrm{~km}$ south of Hawaii. Johnston Atoll is part of the Hawaiian marine biogeographic province because its marine fauna is predominantly Hawaiian [26]. Hence, species that only occur in the Hawaiian Archipelago and Johnston Atoll are still regarded as Hawaiian endemics.

Our study is preceded by a survey of two endemic Hawaiian damselfishes: Stegastes marginatus and Dascyllus albisella [27]. Ramon et al. [27] analyzed the mitochondrial control region (CR) and found genetic structure in both species, in contrast to the majority of reef fishes surveyed across Hawaii, which show no structure within the archipelago using the mitochondrial marker cytochrome $b$ (cytb) [28-31] (but see [32]). Furthermore, one of our study species, C. verater, was the subject of a separate study on connectivity between shallow and mesophotic $(>30 \mathrm{~m})$ reef habitats [33]. No vertical (depth-related) structure was identified in this species, but the Hawaiian Archipelago was significantly differentiated from adjacent Johnston Atoll (cytb: $\Phi_{\mathrm{ST}}=0.0679, P<0.0001$; CR: $\left.\Phi_{\text {ST }}=0.1156, P<0.0001\right)$.

The three damselfishes surveyed for the current study were chosen because they are abundant throughout the entire archipelago and belong to the sister genera of Abudefduf and Chromis [34]. This phylogenetic constraint should reduce variable traits among species. There are a total of eight endemic Hawaiian damselfishes, so utilizing results from the previous studies, we are able to examine phylogeographic patterns across five of these species. Given that two Hawaiian endemic damselfishes already show significant genetic structure, we would predict genetic differentiation across the ranges of A. abdominalis, C. ovalis, and C. verater as well, providing more support for a correlation between range size and dispersal ability. Additionally, this finding may indicate that genetic differentiation is typical of endemic Hawaiian damselfishes.

Results from our study also contribute to the conservation of the Hawaiian Archipelago. The NWHI host the Papahānaumokuākea Marine National Monument, one of the largest marine protected areas in the world and the largest in the US. The degree of connectivity between the NWHI and the MHI is of particular interest to the management of marine resources in the archipelago. The vast and uninhabited marine protected area (NWHI), adjacent to a large community that depends on the sea for nutrition (MHI), is postulated to have a spillover effect $[35,36]$. Our fine-scale sampling throughout the Hawaiian Islands can illustrate whether the NWHI have the potential to subsidize the overexploited reefs of the MHI.

\section{Materials and Methods}

2.1. Tissue Collection. Collections of 345 A. abdominalis, 412 C. ovalis, and 425 C. verater specimens (fin clips) were made at 13-15 locations across the Hawaiian Archipelago from 2009 to 2012 (Figure 1). Additional C. verater specimens were collected at Johnston Atoll $(N=47)$. Collections were made with pole spears or hand nets while snorkeling or SCUBA diving.

\subsection{DNA Extraction, Marker Amplification, and Sequencing.} Tissue specimens were preserved in salt-saturated water with $20 \%$ DMSO [37]. All of the protocols for DNA extraction, marker amplification, and sequencing are identical to those used in Tenggardjaja et al. [33]. Cytb and mitochondrial CR sequences of $C$. verater generated for Tenggardjaja et al. [33] were used in this study. Additionally, since the lab work for the current study was conducted concurrently with the study on A. abdominalis by Coleman et al. [38], cytb sequences of $A$. abdominalis were shared between the authors. Of these sequences, thirteen were identified as hybrids by Coleman et al. [38] and were included in the current study after determining that they did not bias mtDNA analyses. Sequences were aligned using the Geneious aligner and edited using GENEIOUS R6 (Biomatters, LTD, Auckland, $\mathrm{NZ}$ ). Alignments of cytb were unambiguous, while CR contained multiple indels of 1-2 bp. Unique haplotypes for each marker were identified in ARLEQUIN 3.5 [39] and were uploaded to GenBank (KP183329-KP183902, KU842721KU843500).

2.3. Genetic Diversity and Population Structure Analyses. Haplotype diversity $(h)$ and nucleotide diversity $(\pi)$ were calculated in ARLEQUIN. Population structure was assessed using analyses of molecular variances (AMOVAs) and population pairwise $\Phi_{\mathrm{ST}}$ comparisons in ARLEQUIN. The $\Phi_{\mathrm{ST}}$ fixation index incorporates genetic distance and ranges from 0 to 1 , with low values indicating a lack of genetic structure 


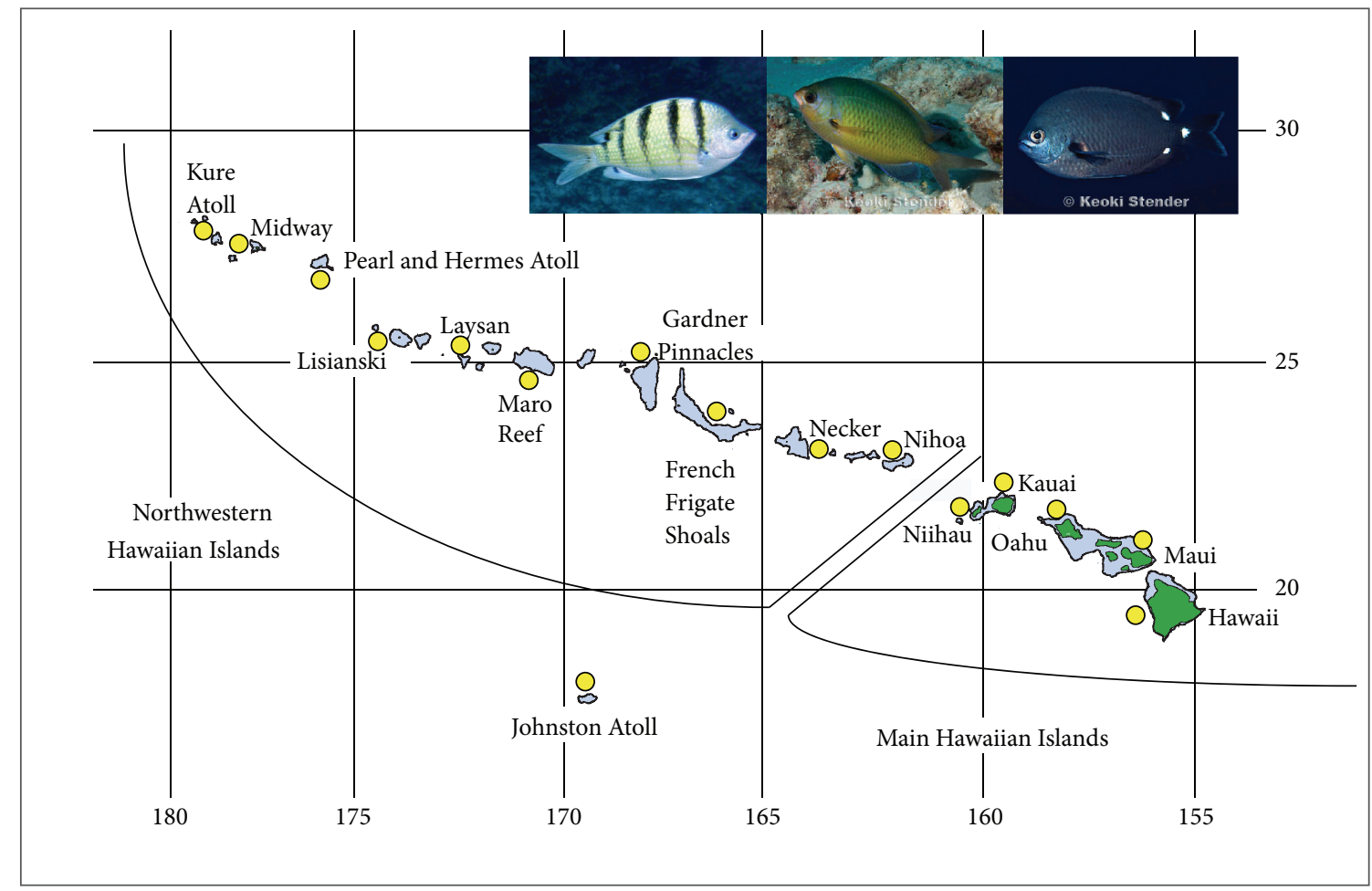

Figure 1: Map of collection locations in the Hawaiian Archipelago and Johnston Atoll for A. abdominalis, C. ovalis, and C. verater (photos left to right). Specimens of all species were collected at each location with the exception of Maro Reef and Johnston Atoll. No C. verater specimens were collected at Maro Reef, and only C. verater specimens were collected at Johnston Atoll. Yellow dots indicate collection locations, green indicates high islands, and blue indicates low islands and shallow habitat. (Photo credit for A. abdominalis: Kim Tenggardjaja. Photo credit for Chromis species: Keoki Stender, http://www.marinelifephotography.com/.)

and high values indicating genetic differentiation. Significance of pairwise $\Phi_{\mathrm{ST}}$ comparisons and AMOVA calculations was tested with 10,000 permutations, and to correct for multiple comparisons, a modified false discovery rate method was implemented [40]. We determined the best model of sequence evolution for each marker in jMODELTEST 2 [41, 42]. Because the models identified by the Akaike information criterion were not available in ARLEQUIN, we selected the Tamura-Nei model as it was the most similar [43]. For $A$. abdominalis, populations at Gardner Pinnacles $(N=1)$ and Nihoa $(N=1)$ were not included in most analyses due to small sample sizes. However, these samples were included in haplotype networks. Parsimony-based haplotype networks for each marker were constructed in $R$ using haploNet in the package Pegas 0.5-1 [44]. Haplotype frequencies used in these networks were calculated in ARLEQUIN.

To test for a signal of population expansion, Fu's $F_{s}$ test for neutrality and mismatch distributions was calculated in ARLEQUIN with 10,000 permutations [45, 46]. Significant negative $F_{s}$ values indicate an excess of rare haplotypes, which can be a signal of selection or, more likely, recent population expansion. For cyt $b$ data, we fitted the population age parameter $\tau$ and pre- and postexpansion population size parameters $\theta_{0}$ and $\theta_{1}$ to estimate the time to coalescence $[46,47]$. Time to coalescence was calculated with $\tau=2 \mu \mathrm{T}$, where $T$ is the age of the population in generations and $\mu$ is the fragment mutation rate. Since the generation times of A. abdominalis, C. ovalis, and C. verater are unknown, we conditionally used a generation time of 3 years based on estimates in the damselfish Chromis chromis [48]. A mutation rate of $2 \%$ per million years between lineages or $1 \%$ within lineages for cyt $b$ was applied [49].

To avoid making a priori assumptions about the locations of genetic barriers, we used the computational geometry approach in BARRIER 2.2 [50] to visualize genetic barriers in geographic space. Genetic barriers represent changes in genetic composition between sample sites. The software identifies barriers with Voronoi tessellation and Delaunay triangulation, implementing Monmonier's maximum-difference algorithm to compare a distance matrix (e.g., matrix of pairwise population $\Phi_{\mathrm{ST}}$ values) with a matrix of geographic distances. A posteriori AMOVAs subsequently were performed on population groupings identified by BARRIER.

Mantel tests were used to test for a correlation between genetic distance and geographic distance. Mantel tests were run in the vegan package in $R$ with 10,000 permutations, using matrices of pairwise $\Phi_{\mathrm{ST}}$ values and geographic distances as calculated by the Geographic Distance Matrix Generator [51, 52]. Mantel tests were performed with matrices that included negative $\Phi_{\mathrm{ST}}$ and also with negative values converted to zeroes. If AMOVAs detected significant structure among groups comprised of more than one 
sample location, partial Mantel tests were run, incorporating a third dissimilarity matrix that took into account the regional structure. Partial Mantel tests can help distinguish whether isolation by distance, or regional population structure, accounts for more genetic variance in data [53].

\section{Results}

A total of $670 \mathrm{bp}$ of cyt $b$ was resolved for A. abdominalis, $660 \mathrm{bp}$ for $C$. ovalis, and $719 \mathrm{bp}$ for $C$. verater. For CR, $400 \mathrm{bp}$ was resolved for A. abdominalis, $388 \mathrm{bp}$ for C. ovalis, and $394 \mathrm{bp}$ for $C$. verater. Summary statistics for number of haplotypes $(H)$, haplotype diversity $(h)$, nucleotide diversity $(\pi)$, and Fu's $F_{s}$ are provided in Table 1 . For $C$. ovalis and $C$. verater, overall haplotype diversity for cyt $b$ was high with $h=0.9501$ and 0.9077 , respectively. Conversely, overall haplotype diversity for cyt $b$ in $A$. abdominalis was lower with $h=0.5865$. For CR, overall haplotype diversity approached saturation for all three species with $h=0.9955-0.9997$.

All three species had negative and significant Fu's $F_{s}$ values for both mtDNA markers at most sample locations (Table 1). Summary Fu's $F_{s}$ values for both markers were negative and significant for all species (cyt $b: F_{s}=-25.6820$ to $-29.8590, \mathrm{CR}: F_{s}=-23.4009$ to -23.7039$)$. Unimodal mismatch distributions in $c y t b$ did not indicate significant deviation from a demographic expansion model for any of the species. Based on a generation time of 3 years and a mutation rate of $2 \%$ per million years ( $1 \%$ within lineages), mismatch analyses indicated the coalescence times to be on the order of 68,000 years for A. abdominalis, 249,000 years for C. ovalis, and 163,000 years for C. verater (Table 2). Since we used estimates for generation time and mutation rate from other species, calculations for coalescence times are approximations at best.

Overall estimates for $\Phi_{\mathrm{ST}}$ varied by marker and by species (Table 3). For A. abdominalis, $\Phi_{\mathrm{ST}}$ based on cyt $b$ was not significant $\left(\Phi_{\mathrm{ST}}=0.0063, P=0.0911\right)$, but $\mathrm{CR}$ yielded weak yet significant genetic structure $\left(\Phi_{\mathrm{ST}}=0.0123, P=0.0034\right)$. For $C$. ovalis, fixation indices for both markers showed weak but significant structure (cyt $b$ : $\Phi_{\mathrm{ST}}=0.0121, P=0.0047$; CR: $\left.\Phi_{\mathrm{ST}}=0.0059, P=0.0370\right)$. Chromis verater had the highest significant $\Phi_{\mathrm{ST}}$ values across the Hawaiian Archipelago and Johnston Atoll (cyt $b$ : $\Phi_{\mathrm{ST}}=0.0232, P<0.0001$; CR: $\Phi_{\mathrm{ST}}$ $=0.0363, P<0.0001)$. When analysis was limited to only the Hawaiian Archipelago, the fixation indices for $C$. verater dropped but remained significant (cyt $b$ : $\Phi_{\mathrm{ST}}=0.0093, P=$ 0.0197; CR: $\Phi_{\mathrm{ST}}=0.0115, P=0.0087$ ).

Pairwise $\Phi_{\mathrm{ST}}$ comparisons revealed different patterns of genetic structure among the sampling locations for each species (Tables 4, 5, and 6). Abudefduf abdominalis had only 6 significant comparisons for cyt $b$, but 19 were significant for CR with 7 of those including comparisons with the sampling location of Niihau, based on $N=8$. BARRIER identified a genetic break between Necker and Niihau, and a posteriori AMOVAs confirmed this as a significant break in both markers (cyt $b$ : $\Phi_{\mathrm{CT}}=0.0107, P=0.0044$; CR: $\Phi_{\mathrm{CT}}=$ $0.0098, P=0.0123)$.

Chromis ovalis had 18 significant comparisons for cytb and 13 for CR, with Pearl and Hermes included in 9 and 4 of these comparisons, respectively. Since most of these comparisons involved populations east of Pearl and Hermes, a posteriori AMOVAs simulating a genetic break between Pearl and Hermes and adjacent Lisianski were run, which detected weak yet significant structure for both markers (cytb: $\Phi_{\mathrm{CT}}=0.0121, P=0.0338$; CR: $\left.\Phi_{\mathrm{CT}}=0.0096, P=0.0287\right)$. AMOVAs did not support any of the genetic breaks identified in BARRIER for this species.

Chromis verater showed significant differentiation of Johnston Atoll in most pairwise comparisons for cyt $b$ and CR (Table 6). Within the Hawaiian Archipelago, the island of Hawaii was significantly different in at least half of the pairwise comparisons for $C$. verater ( 6 for cyt $b$; 6 for CR). BARRIER detected a genetic break between Johnston Atoll and the Hawaiian Archipelago, which was supported by moderate $\Phi_{\mathrm{ST}}$ values $\left(\mathrm{cyt} b\right.$ : $\Phi_{\mathrm{ST}}=0.0679, P<0.0001$; CR: $\left.\Phi_{\mathrm{ST}}=0.1156, P<0.0001\right)$. Also, BARRIER identified a genetic break between Maui and the island of Hawaii, and a posteriori AMOVAs confirmed this as a significant break (cyt $b$ : $\Phi_{\mathrm{CT}}=$ 0.0211, $P=0.0194$; CR: $\Phi_{\mathrm{CT}}=0.0352, P=0.0045$ ).

In addition to examining patterns of genetic structure among sampling locations, we compared the proportion of significant population pairwise $\Phi_{\mathrm{ST}}$ comparisons: (1) within the NWHI, (2) within the MHI, and (3) between the NWHI and the MHI. The greatest proportion of significant comparisons occurred between locations in the NWHI and MHI (Table 7).

Parsimony-based haplotype networks for cyt $b$ were dominated by widely distributed common haplotypes (Figure 2). The network for A. abdominalis, which had the lowest haplotype diversity, was dominated by one common haplotype. Chromis ovalis and $C$. verater, which had similarly high haplotype diversities, had multiple common haplotypes in the networks. In all species, the most common haplotypes were present at nearly every sampling location. In contrast, the networks for CR in all three species showed an abundance of haplotypes observed in single individuals, as expected with haplotype diversities $h>0.9900$ (Figure 3). While there did not appear to be much geographic clustering of haplotypes, the CR haplotype network for C. verater showed some grouping of Johnston Atoll haplotypes, which supports the genetic differentiation from the Hawaiian Archipelago (Figure 3).

For C. ovalis and C. verater, the Mantel test for cyt $b$ did not indicate isolation by distance, but $A$. abdominalis, the species with the lowest overall population structure, had a significant signal ( $r^{2}=0.5308, P=0.0003$ ). Since AMOVAs with $A$. abdominalis populations grouped into the NWHI and the MHI were significant for both markers, a partial Mantel test for cyt $b$ was run accounting for this regional structure. The isolation by distance signal was weaker but still significant $\left(r^{2}=0.4685, P=0.0005\right)$. For CR, no Mantel tests or partial Mantel tests were significant (data not shown). 
TABLE 1: Molecular diversity indices for A. abdominalis, C. ovalis, and C. verater. Number of individuals $(N)$, number of haplotypes $(H)$, nucleotide diversity $(\pi)$, haplotype diversity $(h)$, and Fu's $F_{s}$ are listed for cyt $b$ and CR. $F_{s}$ values in bold are significant $(P<0.05)$. For $A$. abdominalis, populations at Gardner Pinnacles $(N=1)$ and Nihoa $(N=1)$ were not included in most analyses due to small sample sizes.

\begin{tabular}{|c|c|c|c|c|c|c|c|c|c|}
\hline \multirow{2}{*}{ Sample location } & \multirow{2}{*}{$N$} & \multicolumn{2}{|c|}{$H$} & \multicolumn{2}{|c|}{$\pi$} & \multicolumn{2}{|c|}{$h$} & \multicolumn{2}{|c|}{ Fu's $F_{s}$} \\
\hline & & cytb & $\mathrm{CR}$ & cyt $b$ & $\mathrm{CR}$ & cyt $b$ & CR & cytb & $\mathrm{CR}$ \\
\hline \multicolumn{10}{|l|}{ A. abdominalis } \\
\hline \multicolumn{10}{|l|}{$\begin{array}{l}\text { Hawaiian } \\
\text { Archipelago }\end{array}$} \\
\hline Kure & 33 & 7 & 27 & $0.0014 \pm 0.0011$ & $0.0358 \pm 0.0183$ & $0.5833 \pm 0.0944$ & $0.9867 \pm 0.0111$ & -2.9312 & -8.5606 \\
\hline Midway & 48 & 7 & 40 & $0.0012 \pm 0.0010$ & $0.0380 \pm 0.0192$ & $0.5408 \pm 0.0808$ & $0.9920 \pm 0.0061$ & -2.9243 & -18.4921 \\
\hline Pearl and Hermes & 29 & 7 & 27 & $0.0010 \pm 0.0009$ & $0.0335 \pm 0.0173$ & $0.5222 \pm 0.1084$ & $0.9951 \pm 0.0106$ & -4.3629 & -13.3511 \\
\hline Lisianski & 16 & 6 & 15 & $0.0011 \pm 0.0010$ & $0.0333 \pm 0.0177$ & $0.5417 \pm 0.1472$ & $0.9917 \pm 0.0254$ & -3.6160 & -4.5074 \\
\hline Laysan & 32 & 12 & 27 & $0.0018 \pm 0.0013$ & $0.0351 \pm 0.0180$ & $0.7157 \pm 0.0859$ & $0.9839 \pm 0.0144$ & -8.7456 & -9.5195 \\
\hline Maro Reef & 30 & 11 & 25 & $0.0019 \pm 0.0014$ & $0.0347 \pm 0.0179$ & $0.7448 \pm 0.0821$ & $0.9862 \pm 0.0129$ & -6.9081 & -7.9587 \\
\hline $\begin{array}{l}\text { French Frigate } \\
\text { Shoals }\end{array}$ & 29 & 11 & 28 & $0.0012 \pm 0.0010$ & $0.0335 \pm 0.0173$ & $0.6207 \pm 0.1055$ & $0.9975 \pm 0.0099$ & -10.2882 & -16.0317 \\
\hline Necker & 20 & 7 & 20 & $0.0015 \pm 0.0011$ & $0.0345 \pm 0.0181$ & $0.6421 \pm 0.1176$ & $1.0000 \pm 0.0158$ & -3.6691 & -9.9856 \\
\hline Niihau & 8 & 3 & 8 & $0.0007 \pm 0.0008$ & $0.0248 \pm 0.0145$ & $0.4643 \pm 0.2000$ & $1.0000 \pm 0.0625$ & -0.9990 & -2.2287 \\
\hline Kauai & 25 & 6 & 25 & $0.0010 \pm 0.0009$ & $0.0393 \pm 0.0202$ & $0.4267 \pm 0.1216$ & $1.0000 \pm 0.0113$ & -3.3803 & -13.4872 \\
\hline Oahu & 28 & 8 & 27 & $0.0015 \pm 0.0011$ & $0.0337 \pm 0.0174$ & $0.5423 \pm 0.1117$ & $0.9974 \pm 0.0104$ & -4.2214 & -14.9033 \\
\hline Maui & 28 & 10 & 24 & $0.0013 \pm 0.0010$ & $0.0290 \pm 0.0151$ & $0.6349 \pm 0.1043$ & $0.9868 \pm 0.0141$ & -8.3239 & -9.5825 \\
\hline Island of Hawaii & 19 & 6 & 17 & $0.0012 \pm 0.0010$ & $0.0343 \pm 0.0180$ & $0.5380 \pm 0.1330$ & $0.9883 \pm 0.0210$ & -2.9396 & -4.6294 \\
\hline $\begin{array}{l}\text { All of Hawaiian } \\
\text { Archipelago }\end{array}$ & 345 & 44 & 235 & $0.0013 \pm 0.0010$ & $0.0343 \pm 0.0171$ & $0.5865 \pm 0.0318$ & $0.9955 \pm 0.0009$ & -29.8590 & -23.7039 \\
\hline
\end{tabular}

C. ovalis

Hawaiian

Archipelago

Kure

Midway

Pearl and Hermes

$\begin{array}{llll}29 & 22 & 29 & 0.0046 \pm 0.0028\end{array}$

$\begin{array}{lll}38 & 27 & 38\end{array}$

$0.0050 \pm 0.0029$

Lisianski

Laysan

Maro Reef

Gardner Pinnacles

French Frigate

Shoals

Necker

Nihoa

Niihau

Kauai

Oahu

Maui

Island of Hawaii

All of Hawaiian

Archipelago

\section{C. verater}

Hawaiian

Archipelago

Kure

Midway

Pearl and Hermes

Lisianski
$0.0049 \pm 0.0029$

$37 \quad 20 \quad 36$

$\begin{array}{lll}4 & 3 & 4\end{array}$

$0.0028 \pm 0.0024$

$0.0040 \pm 0.0024$

$0.0054 \pm 0.0032$

$0.0057 \pm 0.0034$

$0.0048 \pm 0.0029$

$0.0054 \pm 0.0031$

$0.0043 \pm 0.0026$

$0.0045 \pm 0.0027$

$0.0043 \pm 0.0026$

$0.0048 \pm 0.0028$

$0.0050 \pm 0.0029$

$0.0053 \pm 0.0031$

$0.0049 \pm 0.0028$

$\begin{array}{lll}412 & 144 & 387\end{array}$

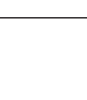

$0.0780 \pm 0.0391$

$0.0679 \pm 0.0339$

$0.0701 \pm 0.0349$

$0.0526 \pm 0.0355$

$0.0691 \pm 0.0346$

$0.0717 \pm 0.0361$

$0.0756 \pm 0.0393$

$0.0691 \pm 0.0347$

$0.0689 \pm 0.0347$

$0.0748 \pm 0.0376$

$0.0665 \pm 0.0340$

$0.0724 \pm 0.0363$

$0.0755 \pm 0.0378$

$0.0719 \pm 0.0361$

$0.0667 \pm 0.0335$

$0.0681 \pm 0.0331$
$0.9778+0.0153$

$0.9659 \pm 0.0177$

$0.9459 \pm 0.0182$

$0.8333 \pm 0.2224$

$0.9015 \pm 0.0432$

$0.9550 \pm 0.0237$

$0.9714 \pm 0.0389$

$0.9613 \pm 0.0191$

$0.9286 \pm 0.0418$

$0.9418 \pm 0.0371$

$0.9474 \pm 0.0435$

$0.9360 \pm 0.0284$

$0.9462 \pm 0.0253$

$0.9729 \pm 0.0173$

$0.9699 \pm 0.0197$

$0.9501 \pm 0.0069$
$1.0000 \pm 0.0091$

$1.0000 \pm 0.0060$

$0.9985 \pm 0.0067$

$1.0000 \pm 0.1768$

$1.0000 \pm 0.0075$

$1.0000 \pm 0.0095$

$1.0000 \pm 0.0243$

$1.0000 \pm 0.0082$

$1.0000 \pm 0.0091$

$1.0000 \pm 0.0095$

$0.9947 \pm 0.0178$

$1.0000 \pm 0.0091$

$1.0000 \pm 0.0082$

$0.9975 \pm 0.0099$

$1.0000 \pm 0.0082$

$0.9997 \pm 0.0002$

$\begin{array}{cc}-20.4731 & -10.9002 \\ -25.2805 & -19.8388 \\ -11.9549 & -15.0322 \\ 0.0062 & 1.0580 \\ -13.6652 & -15.1002 \\ -10.4982 & -10.8746 \\ -8.3469 & -3.2110 \\ -12.3126 & -13.5519 \\ -16.0795 & -12.0406 \\ -19.6826 & -10.5918 \\ -12.9546 & -4.1037 \\ -10.6489 & -11.4865 \\ -12.3276 & -12.4146 \\ -17.0340 & -8.8047 \\ -19.5568 & -13.8980 \\ -25.6820 & -23.4292\end{array}$

0.0331


TABle 1: Continued.

\begin{tabular}{|c|c|c|c|c|c|c|c|c|c|}
\hline \multirow{2}{*}{ Sample location } & \multirow{2}{*}{$N$} & \multicolumn{2}{|c|}{$H$} & \multicolumn{2}{|c|}{$\pi$} & \multicolumn{2}{|c|}{$h$} & \multicolumn{2}{|c|}{ Fu's $F_{s}$} \\
\hline & & cytb & CR & cyt $b$ & CR & cyt $b$ & CR & cytb & CR \\
\hline Laysan & 16 & 11 & 16 & $0.0029 \pm 0.0019$ & $0.0783 \pm 0.0405$ & $0.9083 \pm 0.0633$ & $1.0000 \pm 0.0221$ & -7.3192 & -1.7070 \\
\hline Gardner Pinnacles & 12 & 6 & 12 & $0.0021 \pm 0.0015$ & $0.0855 \pm 0.0452$ & $0.8182 \pm 0.0840$ & $1.0000 \pm 0.0340$ & -2.0878 & -0.0851 \\
\hline $\begin{array}{l}\text { French Frigate } \\
\text { Shoals }\end{array}$ & 39 & 18 & 38 & $0.0027 \pm 0.0018$ & $0.0823 \pm 0.0408$ & $0.8920 \pm 0.0306$ & $0.9987 \pm 0.0062$ & -13.6020 & -14.4092 \\
\hline Nihoa & 36 & 20 & 36 & $0.0036 \pm 0.0022$ & $0.0827 \pm 0.0411$ & $0.9413 \pm 0.0229$ & $1.0000 \pm 0.0065$ & -14.7456 & -15.1230 \\
\hline Niihau & 67 & 34 & 62 & $0.0038 \pm 0.0023$ & $0.0822 \pm 0.0403$ & $0.9439 \pm 0.0164$ & $0.9973 \pm 0.0033$ & -26.6171 & -24.0938 \\
\hline Kauai & 30 & 21 & 27 & $0.0035 \pm 0.0022$ & $0.0797 \pm 0.0399$ & $0.9494 \pm 0.0276$ & $0.9931 \pm 0.0105$ & -19.9573 & -3.6324 \\
\hline Oahu & 72 & 31 & 68 & $0.0029 \pm 0.0018$ & $0.0828 \pm 0.0405$ & $0.8901 \pm 0.0279$ & $0.9984 \pm 0.0026$ & -27.2002 & -24.0863 \\
\hline Maui & 33 & 17 & 31 & $0.0031 \pm 0.0019$ & $0.0797 \pm 0.0397$ & $0.9072 \pm 0.0365$ & $0.9962 \pm 0.0086$ & -11.9743 & -8.1731 \\
\hline Island of Hawaii & 30 & 14 & 30 & $0.0028 \pm 0.0018$ & $0.0818 \pm 0.0409$ & $0.8851 \pm 0.0425$ & $1.0000 \pm 0.0086$ & -8.3701 & -11.0474 \\
\hline $\begin{array}{l}\text { All of Hawaiian } \\
\text { Archipelago }\end{array}$ & 425 & 104 & 392 & $0.0032 \pm 0.0020$ & $0.0786 \pm 0.0380$ & $0.9152 \pm 0.0083$ & $0.9996 \pm 0.0002$ & -26.4923 & -23.4322 \\
\hline Johnston Atoll & & & & & & & & & \\
\hline Johnston Atoll & 47 & 11 & 39 & $0.0025 \pm 0.0016$ & $0.0598 \pm 0.0298$ & $0.6920 \pm 0.0666$ & $0.9880 \pm 0.0082$ & -3.4506 & -11.1614 \\
\hline $\begin{array}{l}\text { Johnston Atoll and } \\
\text { Hawaiian } \\
\text { Archipelago }\end{array}$ & 472 & 109 & 431 & $0.0032 \pm 0.0019$ & $0.0782 \pm 0.0378$ & $0.9077 \pm 0.0089$ & $0.9995 \pm 0.0002$ & -26.4557 & -23.4009 \\
\hline
\end{tabular}

TABLE 2: Estimates of $\tau$, pre and post-expansion theta $\left(\theta_{0}\right.$ and $\left.\theta_{1}\right)$, and coalescence time in years (95\% confidence limit of $\left.\tau\right)$ for A. abdominalis, C. ovalis, and C. verater.

\begin{tabular}{lcccc}
\hline Species & $\tau$ & $\theta_{0}$ & $\theta_{1}$ & Coalescence time (years ago) \\
\hline A. abdominalis & 0.918 & 0 & 15.716 & $68,507(15,746-127,537)$ \\
C. ovalis & 3.297 & 0.035 & 154.375 & $249,773(165,152-295,909)$ \\
C. verater & 2.355 & 0.011 & 99999 & $163,769(143,394-188,943)$ \\
\hline
\end{tabular}

\section{Discussion}

In accordance with the expected relationship between dispersal ability and range size, the Hawaiian endemic damselfishes A. abdominalis, C. ovalis, and C. verater all demonstrated evidence of genetic differentiation. Although the species differed in terms of the specific patterns of connectivity among locations, in general, there was a trend toward more genetic structure between locations in the NWHI and the MHI, which has implications for the management of marine resources in the Hawaiian Archipelago. Additionally, the genetic breaks exhibited by each species were concordant with previously identified barriers to dispersal in the archipelago [32], providing guidance in defining ecosystembased management units.

4.1. Population Structure of Hawaiian Endemic Damselfishes. Our genetic survey based on mitochondrial markers cyt $b$ and CR revealed that these three endemic damselfishes exhibited low but significant population structure within their ranges. Very few migrants per generation are necessary to prevent genetic differentiation between populations [54], so even weak genetic structure that is statistically significant indicates some restriction to gene flow [55]. For each species in this study, global $\Phi_{\text {ST }}$ values were significant within the Hawaiian Archipelago, and each species exhibited multiple significant pairwise $\Phi_{\mathrm{ST}}$ comparisons for both markers. Of the eight endemic Hawaiian damselfishes, the only other species subject to genetic surveys are D. albisella and S. marginatus [27]. Similar to our results, both of these species had multiple significant pairwise $\Phi_{\mathrm{ST}}$ comparisons for the mitochondrial control region. Combining results for those two species with results from the current study, all five endemic damselfishes exhibit significant genetic structure, supporting the hypothesis that the restricted ranges of endemic species are coupled with lower dispersal ability. Without data on the three remaining species Chromis hanui, Chromis struhsakeri, and Plectroglyphidodon sindonis, we cannot definitively conclude that all Hawaiian endemic damselfish species demonstrate population subdivision over their range, but so far all results support this trend.

4.2. Anomalies in $A$. abdominalis. The cytb results for $A$. abdominalis produced several differences from those of $C$. ovalis and $C$. verater: (1) a significant isolation by distance signal, (2) one common haplotype dominating the haplotype network, and (3) lower haplotype diversity. The high mutation rate and higher diversity of the CR may have masked these characteristics in the CR data. While A. abdominalis, C. ovalis, and $C$. verater share similar life history traits, such as spawning seasonality, feeding behavior, and egg type, they differ in PLD. The PLD for A. abdominalis is 17-18 days, while 


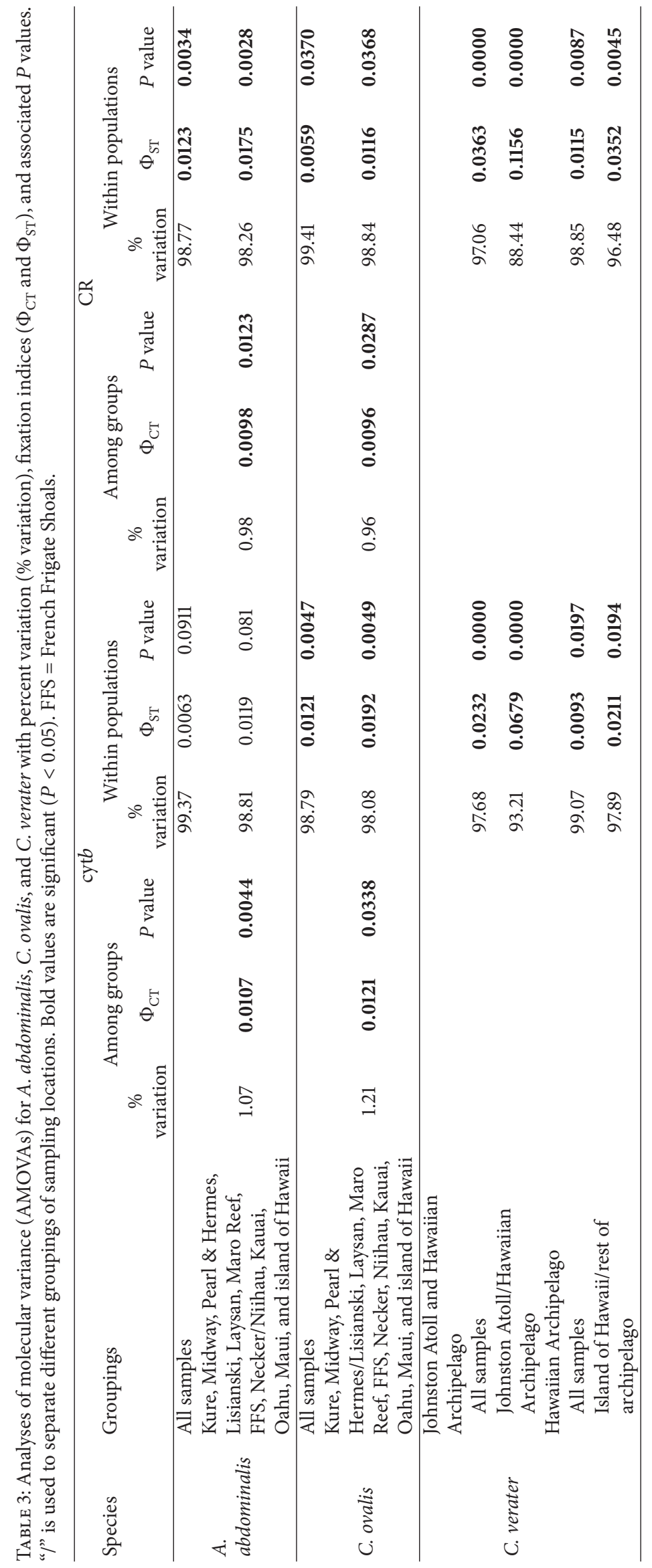




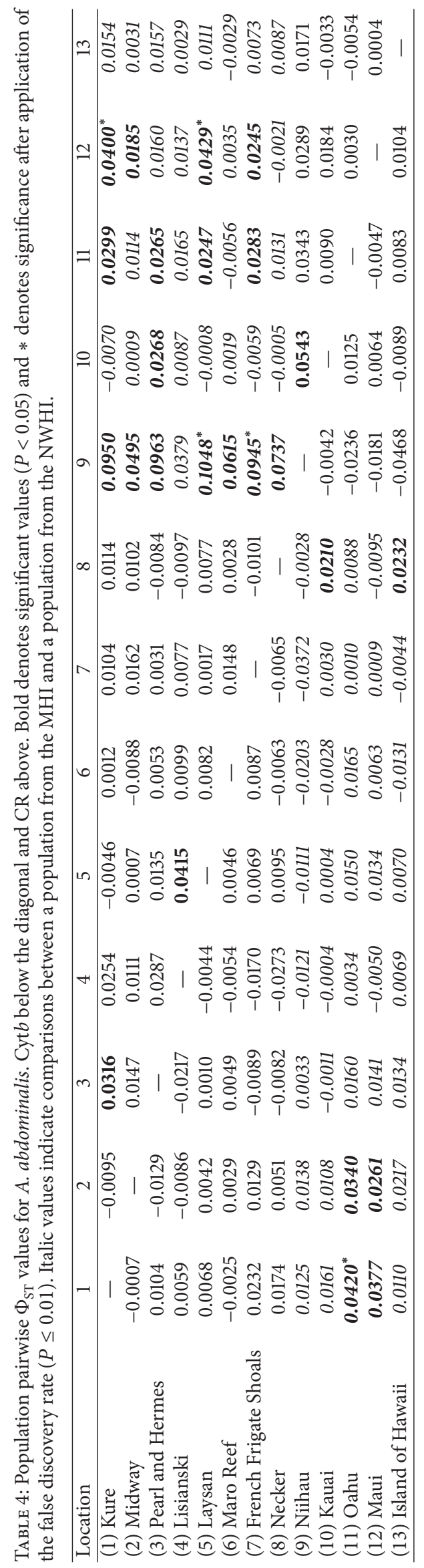




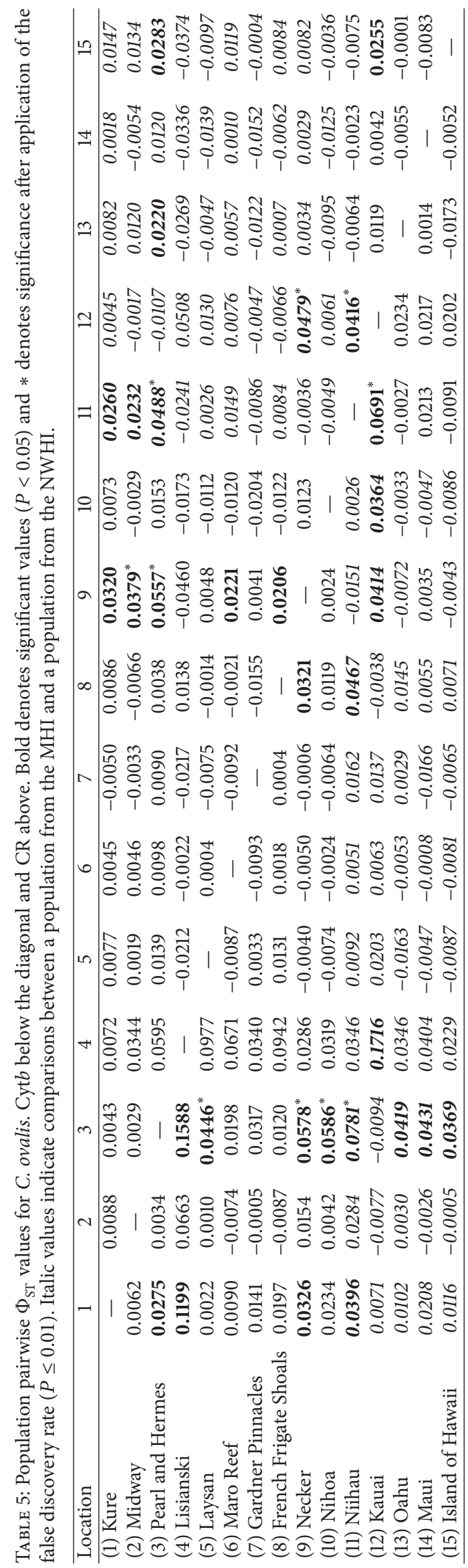




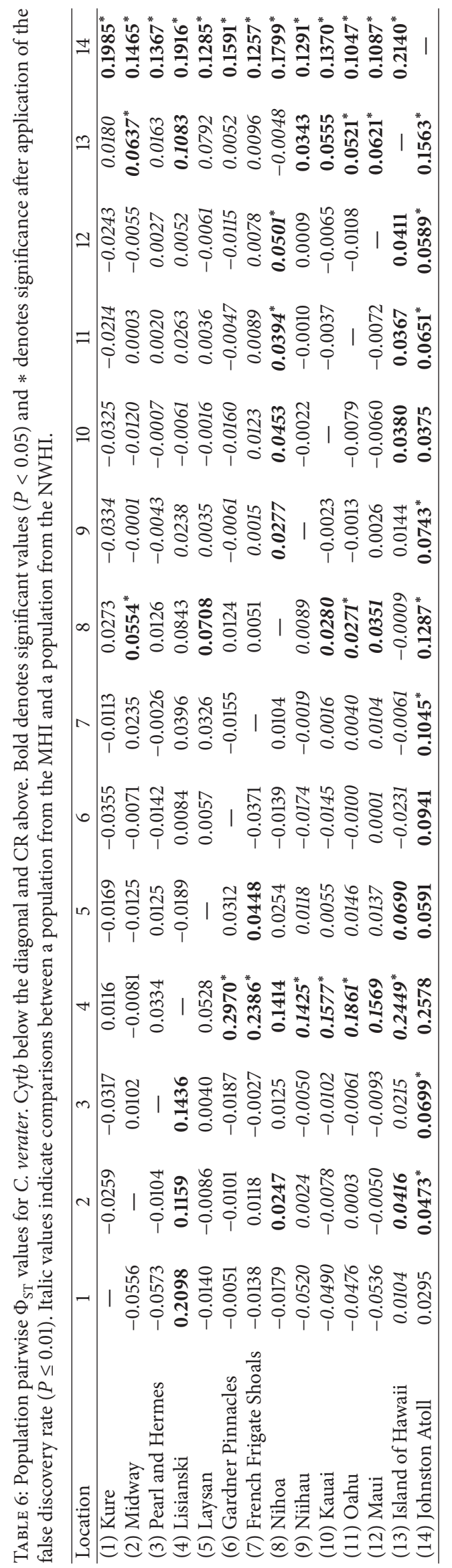




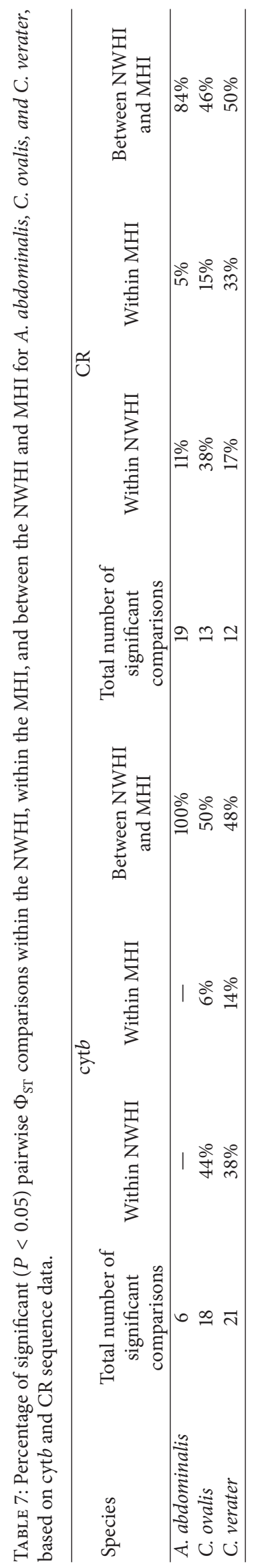




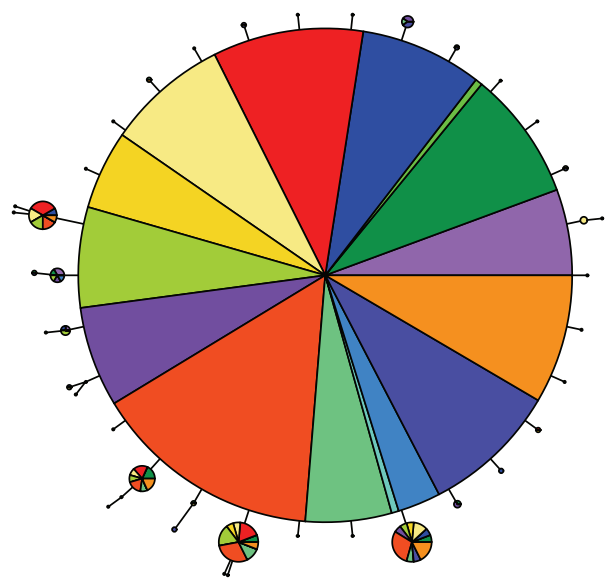

(a)

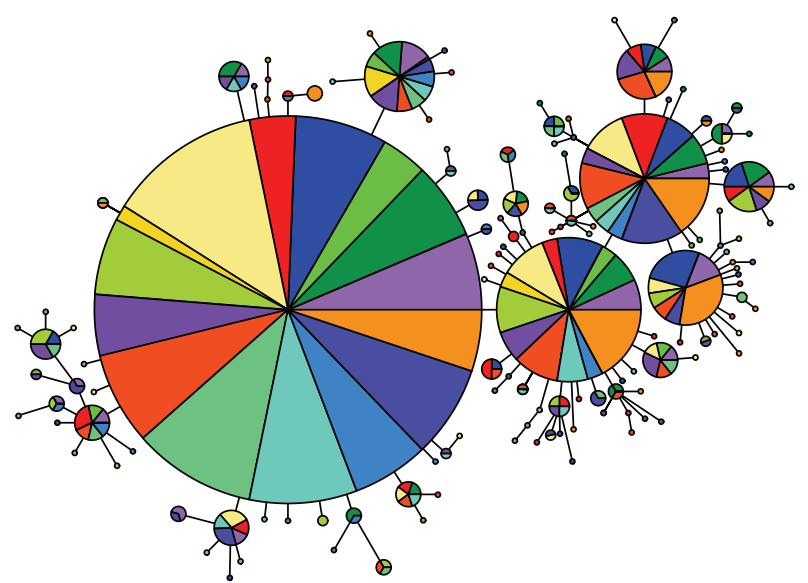

(b)

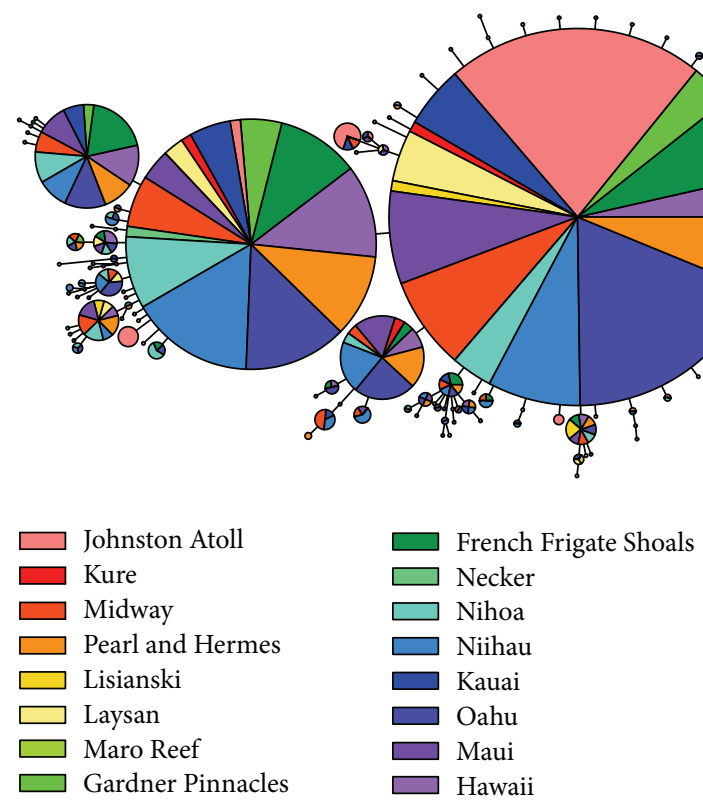

(c)

Figure 2: Parsimony-based haplotype networks using cytb sequence data for (a) A. abdominalis, (b) C. ovalis, and (c) C. verater. Each circle represents a haplotype and is proportional to the frequency of that haplotype. Length of branches is proportional to number of mutations. Networks are color-coded by sampling location and are not scaled relative to each other.

the PLDs for C. ovalis and C. verater are estimated to be 30 days and as long as 3 months, respectively $[13,56]$. The isolation by distance signal for $A$. abdominalis may result from a shorter PLD and thus lower dispersal [17], yet the relationship between PLD and dispersal distance remains controversial [57-59]. One notable result from our data sets is a rank order wherein the species with the longest PLD (C. verater) has the most population structure and the species with the shortest PLD (A.abdominalis) has the least structure, contrary to expectations.

In addition to PLD, the depth ranges for the Chromis species (5-199 m) differ from that of A. abdominalis (1-50 m). Sea level fluctuations during the Pleistocene reduced coastal habitat in the Hawaiian Archipelago by $75 \%$, likely fragmenting populations of many shallow-water marine species [60]. Chromis ovalis and C. verater may have retreated to refugia in the deeper parts of their depth range, while A. abdominalis may have been more susceptible to these changes in sea level [61]. As observed in other marine taxa [60], the refugia populations of the Chromis species may have become genetically differentiated over time and subsequently reestablished connectivity once sea levels rose, resulting in haplotype networks comprised of several common haplotypes. Conversely, in $A$. abdominalis, the network is dominated by a single haplotype, and its lower haplotype diversity may reflect a population bottleneck following sea level change and subsequent population expansion, a pattern found in multiple marine taxa [60]. Significant negative Fu's $F_{s}$ values, unimodal mismatch distributions, and shallow coalescence times reinforce that all three species have experienced recent population expansions, possibly as a result of past fluctuations in climate and sea level. 


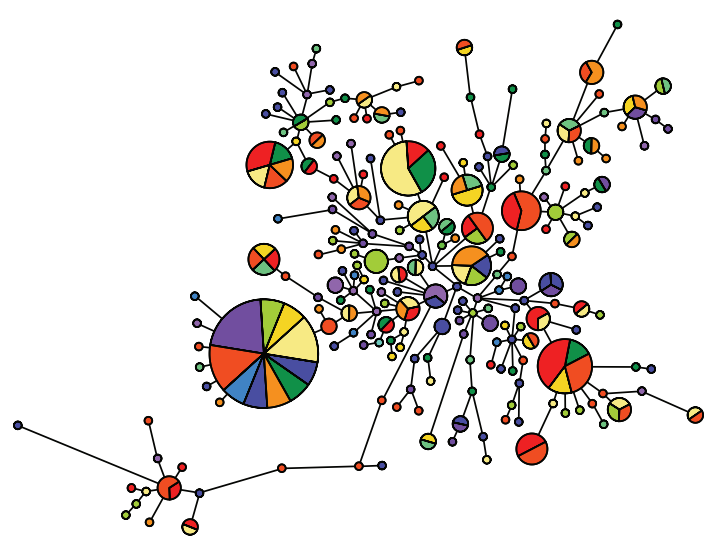

(a)

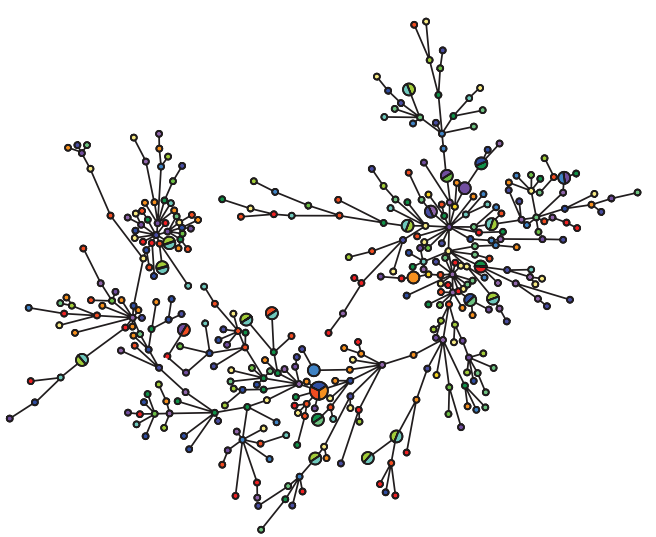

(b)

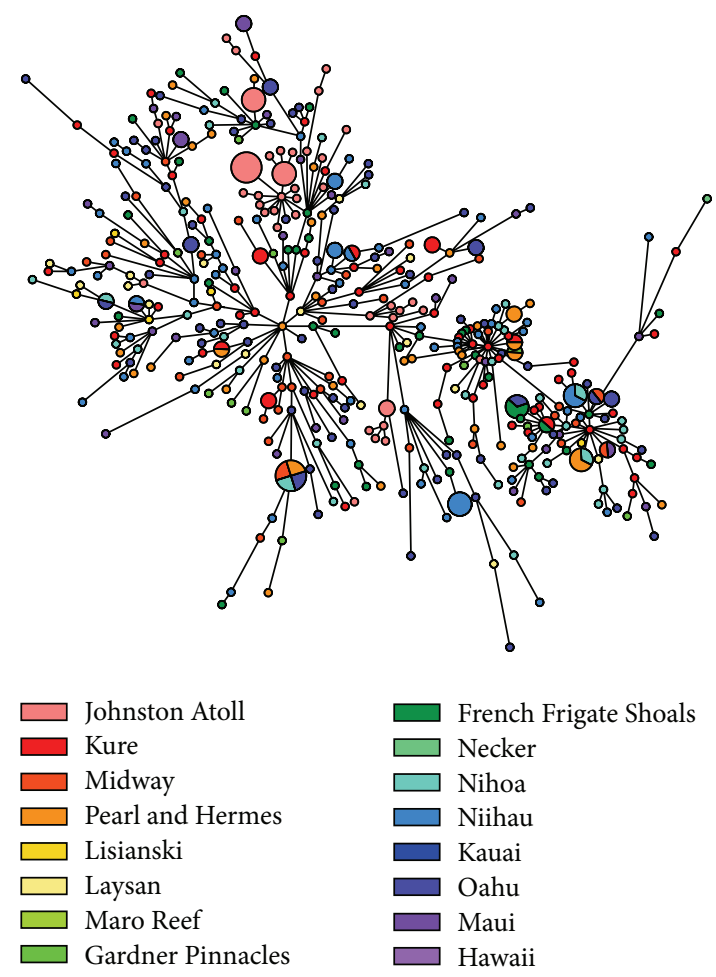

(c)

Figure 3: Parsimony-based haplotype networks using CR sequence data for (a) A. abdominalis, (b) C. ovalis, and (c) C. verater. Each circle represents a haplotype and is proportional to the frequency of that haplotype. Length of branches is proportional to number of mutations. Networks are color-coded by sampling location and are not scaled relative to each other.

4.3. Phylogeographic Patterns of Hawaiian Endemic Reef Fishes. Since multiple genetic surveys exist for endemic Hawaiian reef fishes, we can compare results to investigate the relationship between range size and dispersal ability. Lester and Ruttenberg [20] found a correlation between PLD and range size for certain reef fish families but not for others. The current study demonstrates that most Hawaiian endemic species in the Pomacentridae exhibit genetic structure. The Hawaiian grouper, Hyporthodus quernus, is the only member of Serranidae endemic to the Hawaiian Archipelago and Johnston Atoll. Population pairwise comparisons for $\mathrm{CR}$ and nuclear microsatellite markers demonstrated low but significant structure within the Hawaiian Islands [62]. In contrast, the widespread grouper Cephalopholis argus showed no population structure from the central Pacific (Line Islands) to northeastern Australia, a distance of about $8000 \mathrm{~km}$ [63]. In the surgeonfishes (Acanthuridae), the Hawaiian endemic Ctenochaetus strigosus exhibited low to moderate genetic structure in population pairwise comparisons for cytb [21]. The surgeonfish Zebrasoma flavescens, which occurs across the NW Pacific but is most abundant in the Hawaiian Archipelago, shows multiple population breaks within the archipelago [64]. In the same family, Acanthurus nigroris, which was reclassified as a Hawaiian endemic [65], 
showed low yet significant population structure in pairwise comparisons and a significant global $\Phi_{\mathrm{ST}}$ value across its range, driven by the Johnston Atoll specimens [30]. In the wrasses (Labridae), Halichoeres ornatissimus only exhibited significant genetic differentiation in pairwise comparisons with Johnston Atoll and, otherwise, did not show significant structure within the Hawaiian Islands [66]. Hawaiian endemic butterflyfishes (Chaetodontidae) also lacked population structure, with cyt $b$ data revealing no genetic structure for Chaetodon fremblii, Chaetodon miliaris, or Chaetodon multicinctus [28]. Though some Hawaiian (or North Pacific) endemics show structure and others do not, this should be interpreted against findings for widespread Indo-Pacific fishes that occur in Hawaii, which almost uniformly show a lack of population structure across this archipelago $[29,31$, 67-71].

Besides the Pomacentridae, genetic surveys of Hawaiian endemics are only available for one to three species within other reef fish families, making it difficult to draw robust conclusions regarding whether taxonomic family is a good predictor of the relationship between range size and dispersal ability. Superficially, there appears to be a trend in the families that have genetic data for more than one Hawaiian endemic species. Genetic structure is observed in five endemic damselfishes and in three surgeonfishes, though structure in $A$. nigroris is inconsistent. The three endemic butterflyfishes lacked genetic structure, but surveys of other butterflyfishes indicate that extensive dispersal is a feature of these taxa [7276]. Additional genetic surveys of Hawaiian endemic reef fishes would provide interesting perspective on whether there is consistency in the relationship between range size and dispersal ability at the taxonomic family level.

4.4. Connectivity between the NWHI and the MHI and Concordant Genetic Breaks in the Hawaiian Archipelago. While individual patterns of genetic connectivity among sampling locations varied by species, our study found that that there was more genetic structure between the NWHI and the MHI than within either region (Table 7). Additionally, AMOVAs for A. abdominalis exhibited a significant genetic break between these two regions (Table 3). Results for $D$. albisella and S. marginatus also supported this trend with $57 \%$ and $50 \%$ of respective significant pairwise comparisons occurring between the NWHI and the MHI [27]. Though A. abdominalis, C. ovalis, and C. verater demonstrated weak genetic structure, there is a clear signal of isolation between these two regions. Since these species are only found in the Hawaiian Islands and Johnston Atoll, management plans should take into account spatial patterns of connectivity exhibited by endemic species, in order to preserve the unique biodiversity within this region.

Multispecies genetic surveys are useful for implementing ecosystem-based management and highlighting potential management units [77, 78]. This study detected several significant genetic breaks in the archipelago: (1) between the NWHI and the MHI (A. abdominalis), (2) east of Pearl and Hermes (C. ovalis), and (3) between Maui and the island of Hawaii (C. verater). These breaks are consistent with three previously identified barriers in the Hawaiian Archipelago. Toonen et al. [32] compared genetic surveys of 27 taxonomically diverse species on Hawaiian coral reefs and found four concordant barriers to dispersal, based primarily on reef invertebrates. Agreement between those breaks and the ones in our study contributes to the proposal that these barriers delineate potential zones of resource management. Moreover, the consistency in genetic breaks across different taxonomic groups reinforces the conclusion that abiotic factors play a role in limiting connectivity within the archipelago.

\section{Conclusions}

Based on the results from this study and Ramon et al. [27], the five Hawaiian endemic damselfishes surveyed to date exhibit genetic structure across their ranges. This finding supports a relationship between range size and dispersal ability. However, this would be more strongly supported if widespread damselfish species demonstrated lower genetic structure across the same geographic range as the endemic species. Our review of genetic surveys of Hawaiian endemic reef fishes indicates that the presence of genetic structure in endemic species may be specific to particular taxonomic families. Genetic data on widespread damselfish species in the Hawaiian Archipelago would be useful in teasing apart this trend from the possibility that the life history traits of damselfishes simply predispose them to showing genetic structure [79]. (However, some studies already have demonstrated a lack of structure in damselfish species $[22,78$, 80].) Since our study was limited to the Hawaiian Archipelago and Johnston Atoll, it is difficult to extend our conclusions to other archipelagos, as place-specific abiotic factors (e.g., oceanography, geologic history) undoubtedly contribute to restricting the dispersal of endemic species.

Our results on the Hawaiian endemics A. abdominalis, $C$. ovalis, and $C$. verater not only reinforce previously identified genetic breaks in the Hawaiian Archipelago, but also illustrate a general trend in connectivity in endemic Hawaiian reef fishes. The preservation of marine biodiversity inherently calls for a better understanding of connectivity patterns in endemic species. The genetic structure between locations in the NWHI and the MHI in our study species and in Ramon et al. [27] indicates that the protected status of the Papahānaumokuākea Marine National Monument may not result in replenishment of depleted reef resources in the MHI. Therefore, taking measures to ensure connectivity between protected areas in the MHI will aid in maintaining the biodiversity unique to this archipelago.

\section{Competing Interests}

The authors declare that they have no competing interests.

\section{Acknowledgments}

For assistance with specimen collections, the authors thank Senifa Annandale, Richard Coleman, Joshua Copus, Joseph DiBattista, Joshua Drew, Michelle Gaither, Alexis Jackson, 
Shelley Jones, Corinne Kane, Stephen Karl, Beth Kimokeo, Randall Kosaki, Gary Longo, Keolohilani Lopes, Yannis Papastamatiou, David Pence, Trisha Soares, Frank Stanton, Zoltan Szabo, Tonatiuh Trejo-Cantwell, Jackie Troller, Daniel Wagner, Chad Wiggins, Christie Wilcox, Yumi Yasutake, and the crew of the R. V. Hi'ialakai. They also thank the Papahānaumokuākea Marine National Monument for logistic support; Ed DeMartini for valuable guidance and suggestions; Jimmy O'Donnell for time-saving R scripts; Lisa Chen, Millicent $\mathrm{Lu}$, and Victor Gomez for their assistance in editing the haplotype networks; members of the Bernardi lab and the ToBo lab for intellectual input; and the staff of the DNA sequencing facility at the University of California, Berkeley, for their assistance with DNA sequencing. This study arose from fieldwork and lab work supported by the National Oceanic and Atmospheric Administration Dr. Nancy Foster Scholarship, the Raney Fund for Ichthyology, the Lewis and Clark Fund for Exploration and Field Research, Sigma Xi Grants-in-Aid of Research, the American Academy of Underwater Sciences Kathy Johnston Scholarship, the Lerner Gray Memorial Fund, the Myers Trust, and the Friends of the Long Marine Lab (Kimberly A. Tenggardjaja). Additionally, this study was supported by the National Science Foundation Grant no. OCE-0929031 (Brian W. Bowen), NOAA National Marine Sanctuaries Program MOA Grant no. 2005-008/66882 (R. J. Toonen), and Hawaii Sea Grant no. NA05OAR4171048 (Brian W. Bowen).

\section{References}

[1] M. J. Caley, M. H. Carr, M. A. Hixon, T. P. Hughes, G. P. Jones, and B. A. Menge, "Recruitment and the local dynamics of open marine populations," Annual Review of Ecology and Systematics, vol. 27, pp. 477-500, 1996.

[2] R. K. Cowen, K. M. M. Lwiza, S. Sponaugle, C. B. Paris, and D. B. Olson, "Connectivity of marine populations: open or closed?" Science, vol. 287, no. 5454, pp. 857-859, 2000.

[3] J. B. Shaklee, "Genetic variation and population structure in the damselfish, Stegastes fasciolatus, throughout the Hawaiian Archipelago," Copeia, vol. 1984, no. 3, pp. 629-640, 1984.

[4] G. P. Jones, G. R. Almany, G. R. Russ et al., "Larval retention and connectivity among populations of corals and reef fishes: history, advances and challenges," Coral Reefs, vol. 28, no. 2, pp. 307-325, 2009.

[5] S. E. Swearer, J. S. Shima, M. E. Hellberg et al., "Evidence of self-recruitment in demersal marine populations," Bulletin of Marine Science, vol. 70, no. 1, pp. 251-271, 2002.

[6] G. P. Jones, S. Planes, and S. R. Thorrold, "Coral reef fish larvae settle close to home," Current Biology, vol. 15, no. 14, pp. 13141318, 2005.

[7] S. E. Swearer, J. E. Caselle, D. W. Lea, and R. R. Warner, "Larval retention and recruitment in an island population of a coral-reef fish," Nature, vol. 402, no. 6763, pp. 799-802, 1999.

[8] I. R. Bradbury, B. Laurel, P. V. R. Snelgrove, P. Bentzen, and S. E. Campana, "Global patterns in marine dispersal estimates: the influence of geography, taxonomic category and life history," Proceedings of the Royal Society B: Biological Sciences, vol. 275, no. 1644, pp. 1803-1809, 2008.
[9] S. E. Lester, B. I. Ruttenberg, S. D. Gaines, and B. P. Kinlan, “The relationship between dispersal ability and geographic range size," Ecology Letters, vol. 10, no. 8, pp. 745-758, 2007.

[10] J. S. Reece, B. W. Bowen, D. G. Smith, and A. Larson, "Comparative phylogeography of four Indo-Pacific moray eel species (Muraenidae) reveals comparable ocean-wide genetic connectivity despite five-fold differences in available adult habitat," Marine Ecology Progress Series, vol. 437, pp. 269-277, 2011.

[11] K. A. Selkoe, O. E. Gaggiotti, B. W. Bowen, and R. J. Toonen, "Emergent patterns of population genetic structure for a coral reef community," Molecular Ecology, vol. 23, no. 12, pp. 30643079, 2014.

[12] C. Mora and D. R. Robertson, "Factors shaping the range-size frequency distribution of the endemic fish fauna of the Tropical Eastern Pacific," Journal of Biogeography, vol. 32, no. 2, pp. 277286, 2005.

[13] G. M. Wellington and B. C. Victor, "Planktonic larval duration of one hundred species of Pacific and Atlantic damselfishes (Pomacentridae)," Marine Biology, vol. 101, no. 4, pp. 557-567, 1989.

[14] D. R. Robertson, "Population maintenance among tropical reef fishes: inferences from small-island endemics," Proceedings of the National Academy of Sciences of the United States of America, vol. 98, no. 10, pp. 5667-5670, 2001.

[15] R. S. Waples, "A multispecies approach to the analysis of gene flow in marine shore fishes," Evolution, vol. 41, no. 2, pp. 385400, 1987.

[16] P. J. Doherty, S. Planes, and P. Mather, "Gene flow and larval duration in seven species of fish from the Great Barrier Reef," Ecology, vol. 76, no. 8, pp. 2373-2391, 1995.

[17] A. L. Shanks, B. A. Grantham, and M. H. Carr, "Propagule dispersal distance and the size and spacing of marine reserves," Ecological Applications, vol. 13, no. 1, pp. S159-S169, 2003.

[18] B. C. Victor and G. M. Wellington, "Endemism and the pelagic larval duration of reef fishes in the eastern Pacific Ocean," Marine Ecology Progress Series, vol. 205, pp. 241-248, 2000.

[19] E. B. Brothers and R. E. Thresher, "Pelagic duration, dispersal, and the distribution of Indo-Pacific coral reef fishes," The Ecology of Coral Reefs, vol. 3, no. 1, pp. 53-69, 1985.

[20] S. E. Lester and B. I. Ruttenberg, "The relationship between pelagic larval duration and range size in tropical reef fishes: a synthetic analysis," Proceedings of the Royal Society B: Biological Sciences, vol. 272, no. 1563, pp. 585-591, 2005.

[21] J. A. Eble, R. J. Toonen, and B. W. Bowen, "Endemism and dispersal: comparative phylogeography of three surgeonfishes across the Hawaiian Archipelago," Marine Biology, vol. 156, no. 4, pp. 689-698, 2009.

[22] G. Bernardi, M. L. Ramon, Y. Alva-Campbell et al., "Darwin's fishes: phylogeography of Galápagos Islands reef fishes," Bulletin of Marine Science, vol. 90, no. 1, pp. 533-549, 2014.

[23] G. R. Allen, "Conservation hotspots of biodiversity and endemism for Indo-Pacific coral reef fishes," Aquatic Conservation: Marine and Freshwater Ecosystems, vol. 18, no. 5, pp. 541556, 2008.

[24] J. E. Randall, Shore Fishes of Hawaii, University of Hawaii Press, Honolulu, Hawaii, USA, 1998.

[25] S. P. Juvik, J. O. Juvik, and T. R. Paradise, Atlas of Hawai'i, University of Hawaii Press, Honolulu, Hawaii, USA, 1998.

[26] J. E. Randall, P. S. Lobel, and E. H. Chave, "Annotated checklist of the fishes of Johnston Island," Pacific Science, vol. 39, no. 1, pp. 24-80, 1985. 
[27] M. L. Ramon, P. A. Nelson, E. De Martini, W. J. Walsh, and G. Bernardi, "Phylogeography, historical demography, and the role of post-settlement ecology in two Hawaiian damselfish species," Marine Biology, vol. 153, no. 6, pp. 1207-1217, 2008.

[28] M. T. Craig, J. A. Eble, and B. W. Bowen, "Origins, ages and population histories: comparative phylogeography of endemic Hawaiian butterflyfishes (genus Chaetodon)," Journal of Biogeography, vol. 37, no. 11, pp. 2125-2136, 2010.

[29] M. T. Craig, J. A. Eble, B. W. Bowen, and D. R. Robertson, "High genetic connectivity across the Indian and Pacific Oceans in the reef fish Myripristis berndti (Holocentridae)," Marine Ecology Progress Series, vol. 334, pp. 245-254, 2007.

[30] J. D. DiBattista, C. Wilcox, M. T. Craig, L. A. Rocha, and B. W. Bowen, "Phylogeography of the Pacific Blueline Surgeonfish, Acanthurus nigroris, reveals high genetic connectivity and a cryptic endemic species in the Hawaiian Archipelago," Journal of Marine Biology, vol. 2011, Article ID 839134, 17 pages, 2011.

[31] J. A. Eble, L. A. Rocha, M. T. Craig, and B. W. Bowen, "Not all larvae stay close to home: insights into marine population connectivity with a focus on the Brown Surgeonfish (Acanthurus nigrofuscus)," Journal of Marine Biology, vol. 2011, Article ID 518516, 12 pages, 2011.

[32] R. J. Toonen, K. R. Andrews, I. B. Baums et al., "Defining boundaries for ecosystem-based management: a multispecies case study of marine connectivity across the Hawaiian Archipelago," Journal of Marine Biology, vol. 2011, Article ID 460173, 13 pages, 2011.

[33] K. A. Tenggardjaja, B. W. Bowen, and G. Bernardi, "Vertical and horizontal genetic connectivity in Chromis verater, an endemic damselfish found on shallow and mesophotic reefs in the Hawaiian Archipelago and adjacent Johnston Atoll," PLoS ONE, vol. 9, no. 12, Article ID el15493, 2014.

[34] W. James Cooper, L. L. Smith, and M. W. Westneat, "Exploring the radiation of a diverse reef fish family: phylogenetics of the damselfishes (Pomacentridae), with new classifications based on molecular analyses of all genera," Molecular Phylogenetics and Evolution, vol. 52, no. 1, pp. 1-16, 2009.

[35] R. Goñi, S. Adlerstein, D. Alvarez-Berastegui et al., "Spillover from six western Mediterranean marine protected areas: evidence from artisanal fisheries," Marine Ecology Progress Series, vol. 366, pp. 159-174, 2008.

[36] C. M. Roberts, J. A. Bohnsack, F. Gell, J. P. Hawkins, and R. Goodridge, "Effects of marine reserves on adjacent fisheries," Science, vol. 294, no. 5548, pp. 1920-1923, 2001.

[37] G. Seutin, B. N. White, and P. T. Boag, "Preservation of avian blood and tissue samples for DNA analyses," Canadian Journal of Zoology, vol. 69, no. 1, pp. 82-90, 1991.

[38] R. R. Coleman, M. R. Gaither, B. Kimokeo, F. G. Stanton, B. W. Bowen, and R. J. Toonen, "Large-scale introduction of the IndoPacific damselfish Abudefduf vaigiensis into Hawai'i promotes genetic swamping of the endemic congener A. abdominalis," Molecular Ecology, vol. 23, no. 22, pp. 5552-5565, 2014.

[39] L. Excoffier and H. E. L. Lischer, "Arlequin suite ver 3.5: a new series of programs to perform population genetics analyses under Linux and Windows," Molecular Ecology Resources, vol. 10, no. 3, pp. 564-567, 2010.

[40] Y. Benjamini and D. Yekutieli, "The control of the false discovery rate in multiple testing under dependency," The Annals of Statistics, vol. 29, no. 4, pp. 1165-1188, 2001.

[41] S. Guindon and O. Gascuel, "A simple, fast, and accurate algorithm to estimate large phylogenies by maximum likelihood," Systematic Biology, vol. 52, no. 5, pp. 696-704, 2003.
[42] D. Posada and K. A. Crandall, "MODELTEST: testing the model of DNA substitution,” Bioinformatics, vol. 14, no. 9, pp. 817-818, 1998.

[43] K. Tamura and M. Nei, "Estimation of the number of nucleotide substitutions in the control region of mitochondrial DNA in humans and chimpanzees," Molecular Biology and Evolution, vol. 10, no. 3, pp. 512-526, 1993.

[44] E. Paradis, "Pegas: an R package for population genetics with an integrated-modular approach," Bioinformatics, vol. 26, no. 3, Article ID btp696, pp. 419-420, 2010.

[45] Y. X. Fu, "Statistical tests of neutrality of mutations against population growth, hitchhiking and background selection," Genetics, vol. 147, no. 2, pp. 915-925, 1997.

[46] A. R. Rogers and H. Harpending, "Population growth makes waves in the distribution of pairwise genetic differences," Molecular Biology and Evolution, vol. 9, no. 3, pp. 552-569, 1992.

[47] W. H. Li, "Distribution of nucleotide differences between 2 randomly chosen cistrons in a finite population," Genetics, vol. 85, no. 2, pp. 331-337, 1977.

[48] J. Dulčić and M. Kraljević, "Age, growth and mortality of damselfish (Chromis chromis L.) in the eastern middle Adriatic," Fisheries Research, vol. 22, no. 3-4, pp. 255-264, 1995.

[49] B. W. Bowen, A. L. Bass, L. A. Rocha, W. S. Grant, and D. R. Robertson, "Phylogeography of the trumpetfishes (Aulostomus): ring species complex on a global scale," Evolution, vol. 55, no. 5, pp. 1029-1039, 2001.

[50] F. Manni, E. Guérard, and E. Heyer, "Geographic patterns of (genetic, morphologic, linguistic) variation: how barriers can be detected by using Monmonier's algorithm," Human Biology, vol. 76, no. 2, pp. 173-190, 2004.

[51] P. Ersts, Geographic Distance Matrix Generator (Version 1.2.3), American Museum of Natural History, Center for Biodiversity and Conservation, New York, NY, USA, 2014.

[52] J. Oksanen, F. Guillaume Blanchet, R. Kindt et al., Vegan: Community Ecology Package, R Package Version 2.0-10, 2013.

[53] P. G. Meirmans, "The trouble with isolation by distance," Molecular Ecology, vol. 21, no. 12, pp. 2839-2846, 2012.

[54] F. W. Allendorf and S. R. Phelps, "Use of allelic frequencies to describe population structure," Canadian Journal of Fisheries and Aquatic Sciences, vol. 38, no. 12, pp. 1507-1514, 1981.

[55] S. Planes, "Biogeography and larval dispersal inferred from population genetic analysis," in Coral Reef Fishes: Dynamics and Diversity in a Complex Ecosystem, P. F. Sale, Ed., Academic Press, San Diego, Calif, USA, 2002.

[56] S. N. Swerdloff, The comparative biology of two Hawaiian species of the damselfish genus Chromis (Pomacentridae) [Ph.D. thesis], University of Hawaii, Honolulu, Hawaii, USA, 1970.

[57] E. A. Treml, J. J. Roberts, Y. Chao, P. N. Halpin, H. P. Possingham, and C. Riginos, "Reproductive output and duration of the pelagic larval stage determine seascape-wide connectivity of marine populations," Integrative and Comparative Biology, vol. 52, no. 4, pp. 525-537, 2012.

[58] K. Weersing and R. J. Toonen, "Population genetics, larval dispersal, and connectivity in marine systems," Marine Ecology Progress Series, vol. 393, pp. 1-12, 2009.

[59] C. Mora, E. A. Treml, J. Roberts, K. Crosby, D. Roy, and D. P. Tittensor, "High connectivity among habitats precludes the relationship between dispersal and range size in tropical reef fishes," Ecography, vol. 35, no. 1, pp. 89-96, 2012.

[60] W. B. Ludt and L. A. Rocha, "Shifting seas: The impacts of Pleistocene sea-level fluctuations on the evolution of tropical 
marine taxa," Journal of Biogeography, vol. 42, no. 1, pp. 25-38, 2015.

[61] C. Fauvelot, G. Bernardi, and S. Planes, "Reductions in the mitochondrial DNA diversity of coral reef fish provide evidence of population bottlenecks resulting from Holocene sea-level change," Evolution, vol. 57, no. 7, pp. 1571-1583, 2003.

[62] M. A. J. Rivera, K. R. Andrews, D. R. Kobayashi et al., "Genetic analyses and simulations of larval dispersal reveal distinct populations and directional connectivity across the range of the Hawaiian Grouper (Epinephelus quernus)," Journal of Marine Biology, vol. 2011, Article ID 765353, 11 pages, 2011.

[63] M. R. Gaither, B. W. Bowen, T.-R. Bordenave et al., "Phylogeography of the reef fish Cephalopholis argus (Epinephelidae) indicates Pleistocene isolation across the Indo-Pacific barrier with contemporary overlap in the coral triangle," BMC Evolutionary Biology, vol. 11, no. 1, pp. 189-204, 2011.

[64] J. A. Eble, L. S. Sorenson, Y. P. Papastamatiou, L. V. Basch, R. J. Toonen, and B. W. Bowen, "Escaping paradise: larval export from Hawaii in an Indo-Pacific reef fish, the yellow tang Zebrasoma flavescens," Marine Ecology Progress Series, vol. 428, pp. 245-258, 2011.

[65] J. E. Randall, J. D. Dibattista, and C. Wilcox, "Acanthurus nigros Gunther, a valid species of surgeonfish, distinct from the Hawaiian A. nigroris Valenciennes," Pacific Science, vol. 65, no. 2, pp. 265-275, 2011.

[66] W. B. Ludt, M. A. Bernal, B. W. Bowen, and L. A. Rocha, "Living in the past: phylogeography and population histories of IndoPacific wrasses (genus Halichoeres) in shallow lagoons versus outer reef slopes," PLoS ONE, vol. 7, no. 6, Article ID e38042, 2012.

[67] P. A. Ahti, R. R. Coleman, J. D. DiBattista, M. L. Berumen, L. A. Rocha, and B. W. Bowen, "Phylogeography of Indo-Pacific reef fishes: sister wrasses Coris gaimard and C. cuvieri in the Red Sea, Indian Ocean and Pacific Ocean," Journal of Biogeography, 2016.

[68] K. R. Andrews, V. N. Moriwake, C. Wilcox et al., "Phylogeographic analyses of submesophotic snappers Etelis coruscans and Etelis 'marshi' (family Lutjanidae) reveal concordant genetic structure across the Hawaiian Archipelago," PLoS ONE, vol. 9, no. 4, Article ID e91665, 2014.

[69] M. R. Gaither, S. A. Jones, C. Kelley, S. J. Newman, L. Sorenson, and B. W. Bowen, "High connectivity in the deepwater snapper Pristipomoides filamentosus (Lutjanidae) across the Indo-Pacific with isolation of the Hawaiian Archipelago," PLoS ONE, vol. 6, no. 12, Article ID e28913, 2011.

[70] J. S. Reece, B. W. Bowen, K. Joshi, V. Goz, and A. Larson, "Phylogeography of two moray eels indicates high dispersal throughout the Indo-Pacific," Journal of Heredity, vol. 101, no. 4, pp. 391-402, 2010.

[71] Z. Szabó, B. Snelgrove, M. T. Craig, L. A. Rocha, and B. W. Bowen, "Phylogeography of the manybar goatfish, Parupeneus multifasciatus, reveals isolation of the Hawaiian Archipelago and a cryptic species in the Marquesas Islands," Bulletin of Marine Science, vol. 90, no. 1, pp. 493-512, 2014.

[72] E. Waldrop, J. P. A. Hobbs, J. E. Randall et al., "Phylogeography, population structure and evolution of coral-eating butterflyfishes (Family Chaetodontidae, genus Chaetodon, subgenus Corallochaetodon)," Journal of Biogeography, 2016.

[73] J. D. Dibattista, L. A. Rocha, M. T. Craig, K. A. Feldheim, and B. W. Bowen, "Phylogeography of two closely related Indo-Pacific butterflyfishes reveals divergent evolutionary histories and discordant results from mtDNA and microsatellites," Journal of Heredity, vol. 103, no. 5, pp. 617-629, 2012.
[74] J. D. DiBattista, E. Waldrop, L. A. Rocha, M. T. Craig, M. L. Berumen, and B. W. Bowen, "Blinded by the bright: a lack of congruence between colour morphs, phylogeography and taxonomy for a cosmopolitan Indo-Pacific butterflyfish, Chaetodon auriga," Journal of Biogeography, vol. 42, no. 10, pp. 1919-1929, 2015.

[75] W. O. McMillan and S. R. Palumbi, "Concordant evolutionary patterns among Indo-West Pacific butterflyfishes," Proceedings of the Royal Society of London Series B: Biological Sciences, vol. 260, no. 1358, pp. 229-236, 1995.

[76] M. L. Berumen, G. R. Almany, S. Planes, G. P. Jones, P. SaenzAgudelo, and S. R. Thorrold, "Persistence of self-recruitment and patterns of larval connectivity in a marine protected area network," Ecology and Evolution, vol. 2, no. 2, pp. 444-452, 2012.

[77] K. E. Carpenter, P. H. Barber, E. D. Crandall et al., "Comparative phylogeography of the Coral Triangle and implications for marine management," Journal of Marine Biology, vol. 2011, Article ID 396982, 14 pages, 2011.

[78] J. A. Drew and P. H. Barber, "Comparative phylogeography in Fijian coral reef fishes: a multi-taxa approach towards marine reserve design," PLoS ONE, vol. 7, no. 10, Article ID e47710, 2012.

[79] M. J. Shulman, "What can population genetics tell us about dispersal and biogeographic history of coral-reef fishes?" Austral Ecology, vol. 23, no. 3, pp. 216-225, 1998.

[80] B. G. Curley and M. R. Gillings, "Population connectivity in the temperate damselfish Parma microlepis: analyses of genetic structure across multiple spatial scales," Marine Biology, vol. 156, no. 3, pp. 381-393, 2009. 

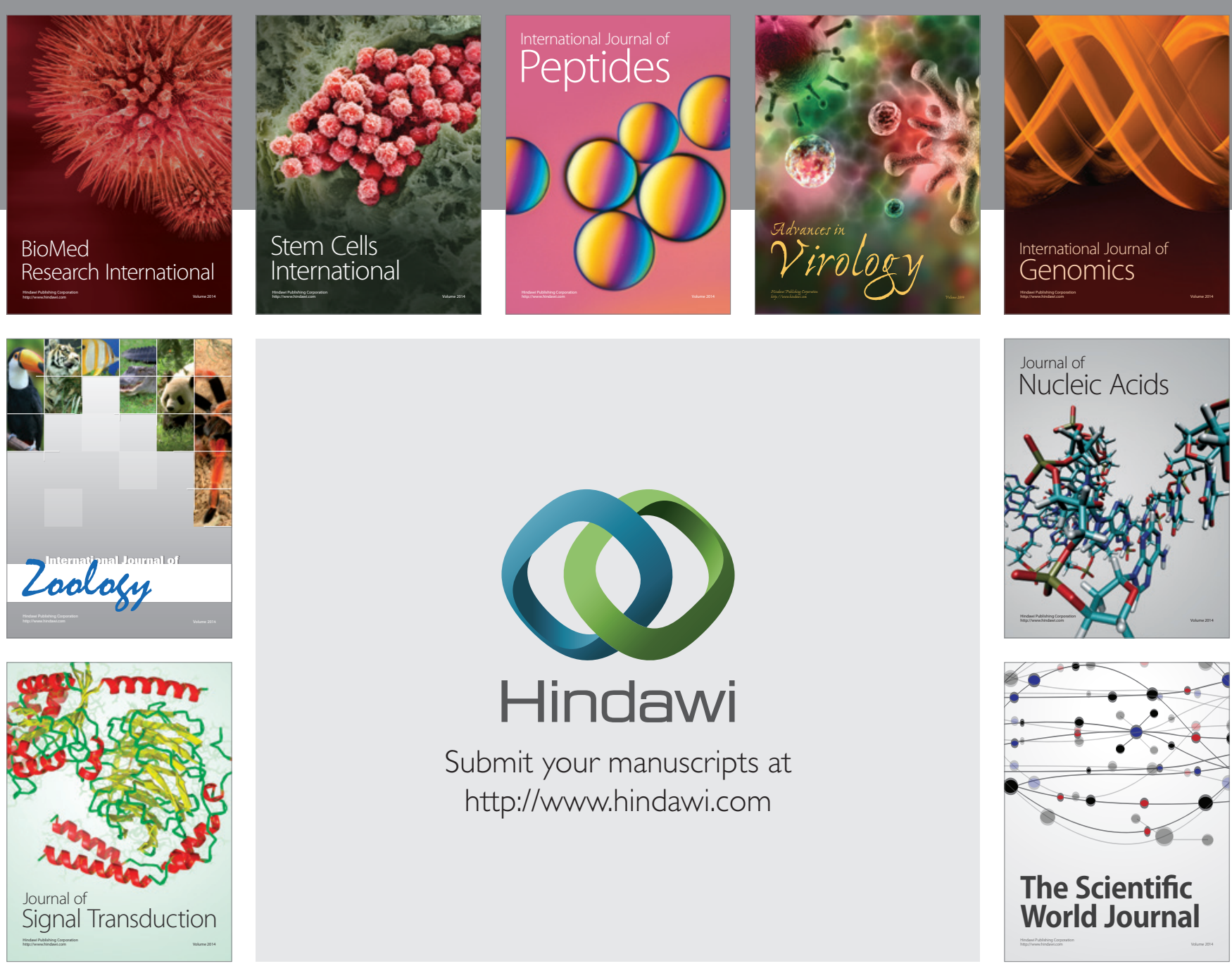

Submit your manuscripts at

http://www.hindawi.com
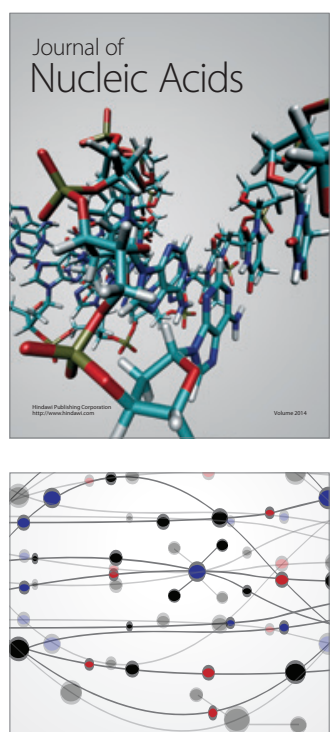

The Scientific World Journal
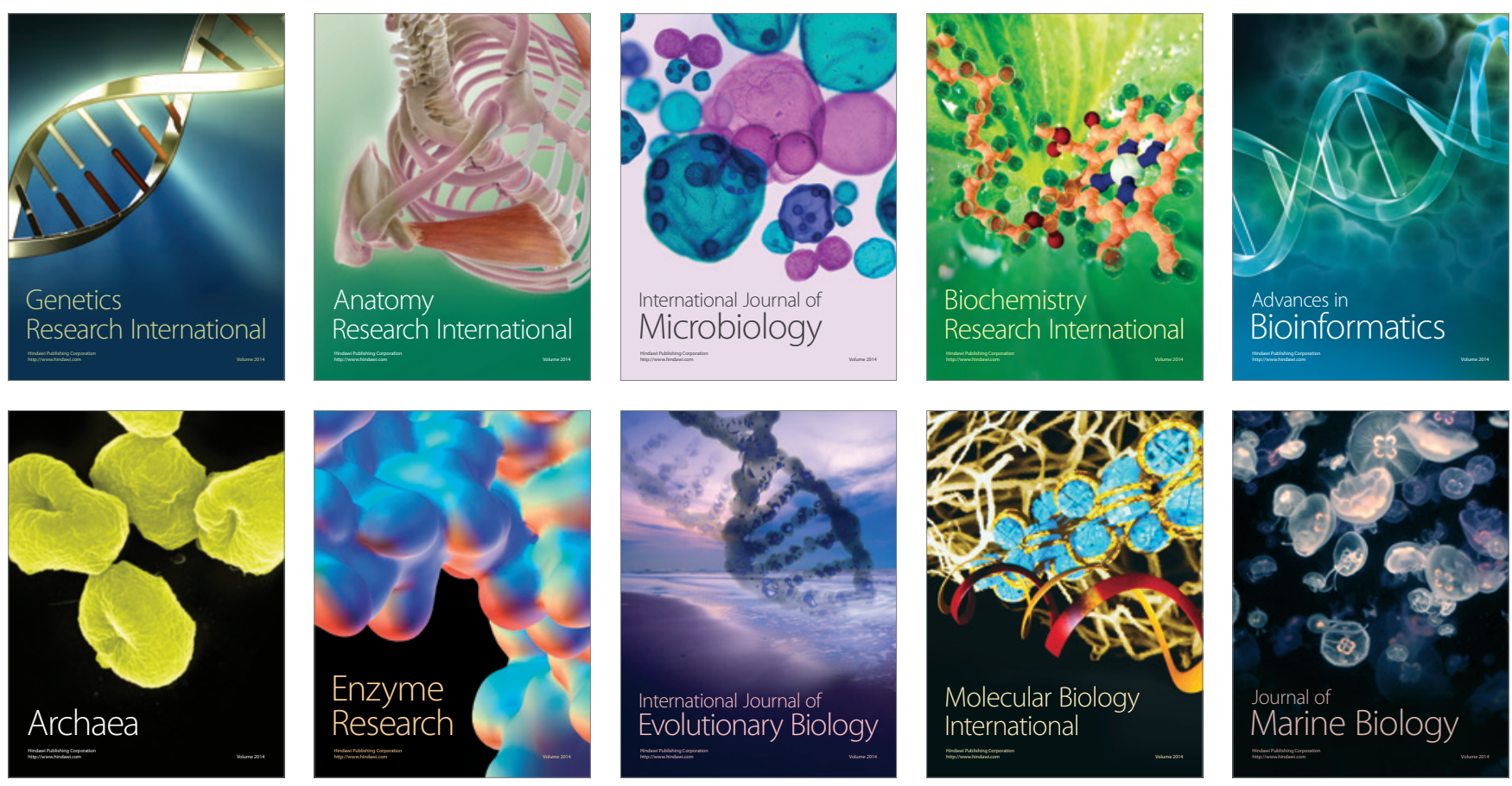